\title{
Patent applications for using DNA technologies to authenticate medicinal herbal material
}

\author{
Pang-Chui Shaw*1,2, Ka-Lok Wong2, Albert Wai-Kit Chan³, Wai- \\ Cheong Wong ${ }^{3}$ and Paul Pui-Hay But ${ }^{2,4}$
}

\begin{abstract}
Address: ${ }^{1}$ Department of Biochemistry, Chinese University of Hong Kong, Shatin, Hong Kong, PR China, ${ }^{2}$ Institute of Chinese Medicine, Chinese University of Hong Kong, Shatin, Hong Kong, PR China, ${ }^{3}$ Law Offices of Albert Wai-Kit Chan, PLLC, Whitestone, New York 11357, USA and ${ }^{4}$ Department of Biology, Chinese University of Hong Kong, Shatin, Hong Kong, PR China

Email: Pang-Chui Shaw* - pcshaw@cuhk.edu.hk; Ka-Lok Wong - klwong@cuhk.edu.hk; Albert Wai-Kit Chan - akitchan@aol.com; WaiCheong Wong-wongw@kitchanlaw.com; Paul Pui-Hay But-paulbut@cuhk.edu.hk

* Corresponding author
\end{abstract}

Published: 24 November 2009

Chinese Medicine 2009, 4:21 doi:|0.1|86/|749-8546-4-2|

This article is available from: http://www.cmjournal.org/content/4/I/2I

(c) 2009 Shaw et al; licensee BioMed Central Ltd.

This is an Open Access article distributed under the terms of the Creative Commons Attribution License (http://creativecommons.org/licenses/by/2.0), which permits unrestricted use, distribution, and reproduction in any medium, provided the original work is properly cited.

\begin{abstract}
Herbal medicines are used in many countries for maintaining health and treating diseases. Their efficacy depends on the use of the correct materials, and life-threatening poisoning may occur if toxic adulterants or substitutes are administered instead. Identification of a medicinal material at the DNA level provides an objective and powerful tool for quality control. Extraction of highquality DNA is the first crucial step in DNA authentication, followed by a battery of DNA techniques including whole genome fingerprinting, DNA sequencing and DNA microarray to establish the identity of the material. New or improved technologies have been developed and valuable data have been collected and compiled for DNA authentication. Some of these technologies and data are patentable. This article provides an overview of some recent patents that cover the extraction of DNA from medicinal materials, the amplification of DNA using improved reaction conditions, the generation of DNA sequences and fingerprints, and the development of high-throughput authentication methods. It also briefly explains why these patents have been granted.
\end{abstract}

\section{Background}

Herbal medicines are used in many countries; unlike chemical drugs, herbal preparations often consist of a combination of materials. Life-threatening poisoning may occur if toxic adulterants or substitutes are used instead. In 1989, two individuals in Hong Kong suffered serious neuropathy and encephalopathy after consuming a broth made with the roots of Podophyllum hexandrum (Taoerqi), a toxic herb mistaken as Gentiana rigescens (Dianlongdan) [1]. In 2001, 63 people in the Netherlands reported symptoms of general malaise, nausea, and vom- iting 2 to 4 hours following consumption of an herbal tea containing Illicium anisatum (Japanese star anise) [2]. Aristolochic acid nephropathy has also been reported in Hong Kong [3], Korea [4], and Belgium [5] as a result of herbs contaminated with aristolochic acids.

Herbal medicinal products of high quality are essential for consumer confidence. Many countries and regions have set up quality standard tests for imported herbal medicine. For example, 324 Chinese medicinal materials are regulated by the Department of Health in Taiwan [6]. 
Herbal manufacturers must label their product with the names of the herbs in the product, and products without such labels are prohibited from entering Taiwan.

Herbal medicinal materials are traditionally identified by their organoleptic or microscopic characteristics, including size, shape, color, odor, flavor, texture and other physical properties. Although the methods based on these characteristics are simple, their accuracy strongly depends on the experience of the inspector, who may or may not be aware of the subtle differences in the structures among related species. Chemical analysis is powerful but the results are affected by the physiological and storage conditions of the herbs. Closely related species containing similar chemical components may also confuse the identification.

DNA technology provides a useful and independent tool to complement chemical analyses for the authentication and quality assurance of medicinal materials. DNA technology offers four advantages: (1) DNA-based markers are less affected by age and physiological conditions; (2) any part of the herb can be collected for analysis; (3) only a small sample is necessary for analysis; and (4) some DNA regions may be species-specific, whereas others may be family-specific.

The principles and techniques of DNA methods were recently reviewed $[7,8]$. Therefore, only a brief account of the popular techniques for DNA authentication is given as an introduction.

A major approach in DNA authentication is wholegenome fingerprinting. The common methods include random amplified polymorphic DNA (RAPD) [9], simple sequence repeat (SSR) [10], amplified fragment length polymorphism (AFLP) [11], and direct amplification of length polymorphism (DALP) [12]. These methods do not require any prior knowledge of the target DNA sequence and, in general, allow for quick identification of genetic polymorphism [13-16].

Owing to the processing procedures, DNA of herbal material is usually somewhat degraded. For accurate DNA fingerprints, attention must be paid to certain defined regions of the genome. Approaches available include polymerase chain reaction-restriction fragment length polymorphism (PCR-RFLP) [17-19] and sequence characterized amplified region (SCAR). The latter involves first sequencing the polymorphic bands from the wholegenome fingerprinting and then using them as reference markers. Multiplex PCR may be employed to examine several SCAR markers simultaneously $[20,21]$.
DNA sequencing is the most definitive means for revealing the identity of an unknown sample [22]. For highthroughput authentication, DNA microarrays may be used. The steps include designing specific probes for a species, fabricating them onto a support, hybridizing with fluorescent-labeled fragments amplified from the genomic DNA of the herbal mixture and reading the hybridization signals with a scanner. A DNA microarray has been established for the identification of a Dendrobium species from a medicinal formula containing nine herbal components [23] and for the differentiation of Dendrobium officinale from other Dendrobium species [24].

In this article, we first outline the procedures of patent application for readers who are not familiar with the process. Then, we describe the existing patents for using DNA methods to authenticate medicinal materials and illustrate how they overcome the limitations of the existing technologies. We also evaluate their market potential and suggest ways to improve them. We hope readers will appreciate how existing DNA technologies may be applied in novel ways for the authentication of medicinal materials as well as opportunities for patent application.

\section{Patents and the application process}

For a United States (US) patent to be issued, an invention must be novel, non-obvious, and useful [25]. Section 101 of Title 35 of the US Codes (35 USC \$101) states that " $[\mathrm{w}$ ]hoever invents or discovers any new and useful process, machine, manufacture, or composition of matter, or any new and useful improvement thereof, may obtain a patent therefore, subject to the conditions and requirements of this title." Furthermore, " [a] patent may not be obtained though the invention that is not identically disclosed or described ..., if the differences between the subject matter sought to be patented and the prior art are such that the subject matter as a whole would have been obvious at the time the invention was made to a person having ordinary skill in the art to which said subject matter pertains" (35 USC \$103). The patentee is granted the right to exclude others from making, using, offering to sell or importing the invention into the US for a period of 20 years from the date of filing the patent application. There are three types of patents in the US, namely utility, design, and plant patents. Patents for biotechnology are mostly utility patents.

The process starts with filing an application with the US Patent and Trademark Office (USPTO) (Figure 1). The application should include a written description (also known as specification) of the invention and of the manner and process of making and using it in full, clear, concise and exact terms to enable a person skilled in the art to make and use the invention. In addition, the application must describe the best mode considered by the inventor 


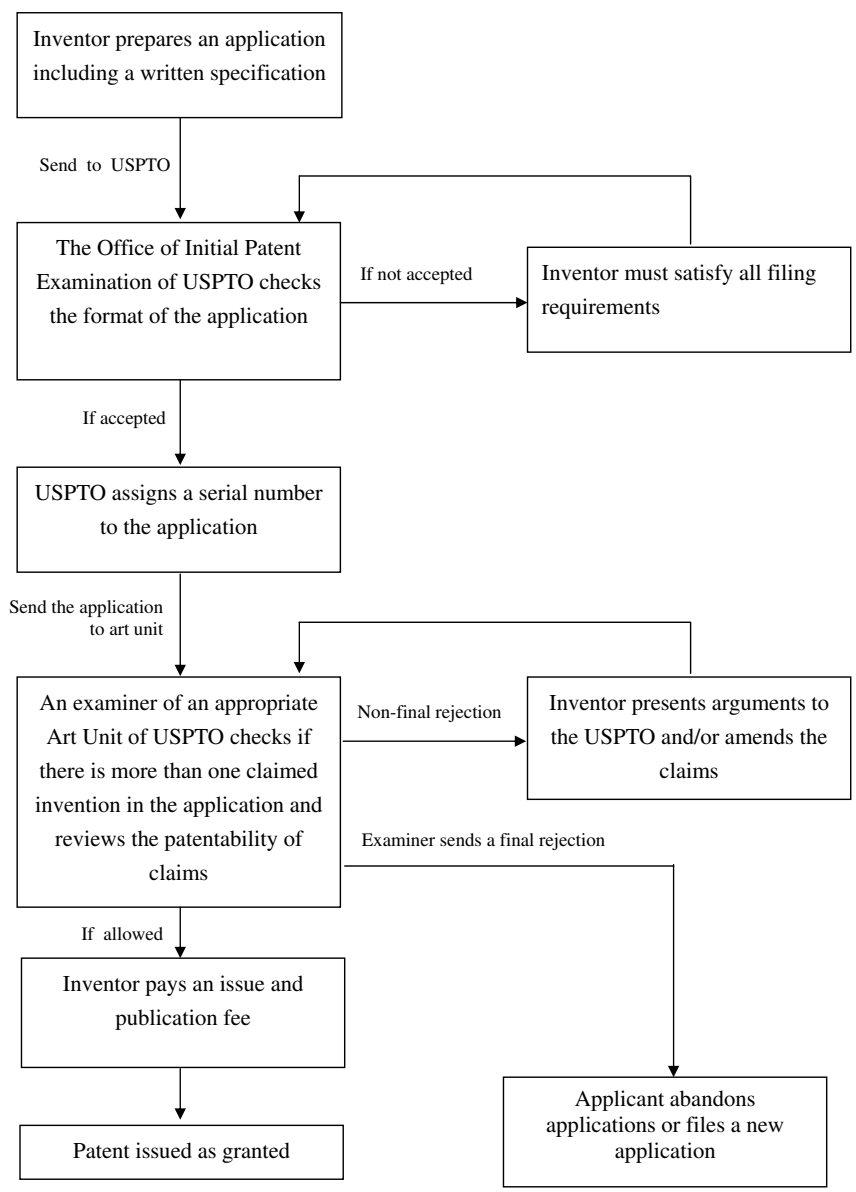

Figure I

Flow chart for US patent application [25].

of carrying out the invention. The application should also include at least one claim setting forth the metes and bounds of the subject matter to be protected. The Office of Initial Patent Examination of the USPTO reviews the application to see if all initial requirements have been met. The application is then assigned a serial number, and an examiner from the relevant art unit of the USPTO is assigned to assess the application [26]. The examiner will assess the claims on their merits. If objections or rejections to some or all of the claims are raised, the applicant will be given an opportunity to amend the claims and/or refute the objections or rejections, until the examiner is convinced that the claims are allowable. After receiving a notice of allowance and paying an issue fee, the applicant will receive a patent on the invention as defined by the allowed claims.

A Chinese patent may be obtained by applying to the State Intellectual Property Office (SIPO) of the People's Repub- lic of China [27]. Unlike in the US where the first person who invents is honored, in China's system the first person who invents and files an application for a patent is entitled to a patent. In the US, an inventor has one year from the date of the first public disclosure of an invention to file an application for patent protection, whereas China does not usually allow such a grace period. Apart from these differences, the US and China have similar criteria for patentability regarding what is known as a utility patent. The Chinese Guidelines for Examination issued in 2006 by the SIPO uses the term "inventive step" instead of "non-obviousness" for judging the patentability. In Article 22.3 of the guidelines, " [i]nventive step of invention means that, as compared with the existing technology before the date of filing, the invention has prominent substantive features and represents notable progress." An invention is said to have prominent substantive features if, "having regard to the prior art, it is non-obvious to a person skilled in the art" (Guidelines for Examination). In 
other words, " [i]f the person skilled in the art can obtain the invention just by logical analysis, inference or limited experimentation on the basis of the prior art, the invention is obvious and therefore has no prominent substantive features" (Guidelines for Examination).

A utility patent in the US is equivalent to an invention patent in China. However, like many other countries, China has what are known as utility model patents, which are reserved for "any new technical solution relating to the shape, the structure, or their combination, of a product, which is fit for practical use" (Guidelines for Examination). Although a utility model patent is usually issued much faster than an invention patent because of the less stringent examination process, protection from a utility model patent is only good for 10 years as compared to 20 years for an invention patent. The inventions described later in this article probably cannot be protected by a utility model patent except for the matrix mill under US Patent 6063616.

To obtain patent protection in multiple countries, inventors may file an international application under the Patent Cooperation Treaty. The United States and China are among the approximately 139 contracting countries of the treaty. After filing an international application, the applicant has a period of typically 30 to 31 months following the priority date (usually the filing date of a prior application that the international application claims priority of) to file national stage applications in any of the contracting countries. An international search report and written opinion are normally issued by an international searching authority for the international application prior to the timeline to enter a national stage. These reports cite any prior art and give an initial evaluation on patentability of the claims, so the applicant would have an opportunity to determine if and where he or she wants to seek protection of the invention. If applications are then submitted to individual countries, they will be examined based on the international written opinion and according to local patent laws and rules. Any patent later issued will be enforceable only within the country of issue.

Since the 1990s, DNA techniques have become popular for the authentication and quality control of Chinese medicinal material. For the protection of intellectual properties and opportunities for commercialization, patents have been applied for the extraction of DNA from medicinal material, amplification of DNA from difficult templates, generation of species-specific fingerprints and sequences, and high-throughput detection and identification of unknown DNA. In this article, recent US and Chinese patents relating to the extraction and amplification of DNA and the generation of DNA fingerprints and sequences for Chinese medicinal materials are described as examples for explaining why some of these patents have been allowed (Additional file 1) while other applications were abandoned (Additional file 2) so that the readers can appreciate the criteria.

\section{Patents for extraction of nucleic acids}

The first step in DNA extraction is to grind or cut the sample into small pieces. Traditionally, this has been achieved by methods that use chemical, sonic wave, mechanical, or physical pressure systems. Sometimes hazardous liquid nitrogen or mortar and pestle are used. As such, these methods are often expensive, require too much effort for large-scale extractions, and provide low throughput. To accelerate and simplify the extraction process, Weeden $e t$ al. invented an innovative matrix mill (US Patent 6063616) that can isolate genomic DNA from numerous samples simultaneously [28]. Samples are added into a 96-well plate and a micropestle composed of a ferrous core coated with a non-reactive material being inserted into each tube (Figure 2). The plate is then placed onto the matrix mill, which provides electromagnetic energy for the movement of the pestle inside the tubes and acts as the random motion of a manual mortar and pestle. Studies showed that this matrix mill gave excellent DNA extracts for tissue types including pea, bean, cucumber, pepper and broccoli. Up to 96 samples can be prepared in each run, and the quality of DNA is sufficient for PCR. The authors believe that adding a chilling device to the matrix

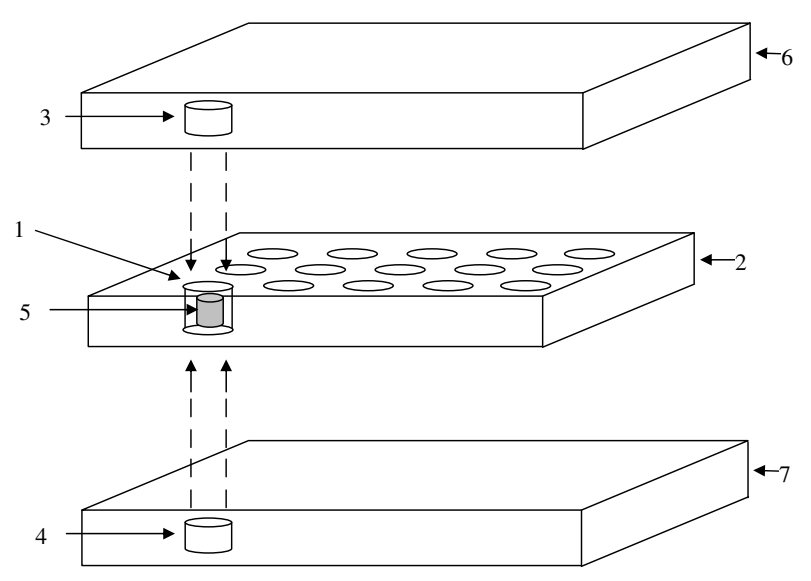

\section{Figure 2}

Drawing and operation of the matrix mill for DNA extraction (adopted from US Patent 60636 I 6). Sample is first added into the well (I) of the assay plate (2). The assay plate is then placed into the matrix mill with upper and lower magnetic core and coil assemblies $(3,4)$ in proximity. The grinding rod (5) is inserted into the well (I). Once alternating current passes through the upper coil assemblies $(3,4)$ in the frames $(6,7)$, the magnetically active grinding rod (5) begins the maceration of the sample material within the well. 
mill would be beneficial because the sample can then be processed under low temperature to avoid the degradation of DNA and RNA samples. Reducing the size of the micropestle would expand the capacity of the mill to a 384-plate format.

DNA with a high molecular weight that is free from contaminants ensures the success of molecular authentication. Generally, lysis buffer for DNA extraction comprises buffering ions, surfactants, chelators and proteinase. Chelators such as EDTA can bind to the free divalent ions to inhibit the enzymatic activities of some nucleases. Proteinase $\mathrm{K}$ digests the tissue or cell membrane and increases the yield of extraction. However, this $\mathrm{Ca}^{2+}$-dependent enzyme may not have a significant effect because divalent ions in the buffer are tightly bound to the chelators. US Patent 7214484 was issued for a lysis buffer that does not require a high concentration of chelators, allowing proteinase $\mathrm{K}$ to effectively digest the protein molecules in a sample and resulting in an increase in the efficiency of cell lysis [29]. This method is more effective in extracting DNA from animal than herbal material, as the former has higher protein content than the latter. To improve the lysis buffer for DNA extraction, we propose modifying proteinase $\mathrm{K}$ to make it less ion-dependent or replacing proteinase $\mathrm{K}$ altogether with a proteinase that is ion-independent.

For DNA isolation, organic solvents such as phenol and chloroform are commonly used. After centrifugation, DNA stays in the upper aqueous phase, whereas protein contaminants are denatured and partitioned either with the organic phase or at the interface between the organic and aqueous phases. The aqueous phase containing DNA molecules is then aspirated. However, the aspirated aqueous phase is sometimes contaminated with organic solvent because the aqueous-organic interface is not very stable. Non-polar phenolic compounds of the herbal material may inhibit downstream reactions, such as PCR. US Patent 5106966 was issued for an innovative DNA extraction method using polyester silica gel in the extraction medium [30]. Before centrifugation, polyester silica gel is placed in the bottom of the tube. This gel moves and separates the aqueous phase from the organic phase after centrifugation, acting as a barrier to permit decanting of the aqueous solvent. This method produces $40 \%$ more DNA than the one without polyester silica gel. Moreover, the ratio of absorbance at $260-280 \mathrm{~nm}$ of the purified DNA is consistently 1.8 , which means the purified preparation is free from protein contamination.

\section{Patents for the amplification of difficult templates}

After extracting the genomic DNA of the medicinal material, the next step is to employ PCR to generate a DNA fingerprint or obtain a particular region for further study.
PCR is an enzymatic reaction that can amplify a defined region of the template DNA from a tiny amount of source material. It has become an indispensable technique used in biological research and has broad applications in DNA cloning, DNA sequencing, molecular phylogenetics, and molecular diagnosis. The PCR patent was granted to Cetus Corporation in 1987 [31] and later sold to Roche Molecular Systems. Since the invention in 1984, many related patented techniques have been developed, such as directional cloning for inserting a gene in a correct frame [32], multiplex PCR for amplifying multiple regions of genomic DNA [33], reverse transcription PCR for amplifying a defined piece of RNA [34], and hot-start PCR for increasing the specificity of the reaction [35]. Some of these patented techniques have been adopted for the amplification and cloning of DNA from medicinal material.

PCR may produce a negative result due to the presence of inhibitors or the secondary structure of the template or primer. The secondary structure of primers reduces the efficiency or even inhibits the binding process. High GC content of the DNA template in some medicinal materials also increases the melting temperature and makes the amplification process difficult. Some researchers tried to solve the problem by increasing the denaturation temperature from the conventional $94^{\circ} \mathrm{C}$ to $98^{\circ} \mathrm{C}$ or extending the denaturation time. Nevertheless, DNA polymerase may lose its activity under prolonged elevated temperature conditions. As such, the reaction buffer must be modified to protect DNA polymerase from degradation. US Patent 7150980 was issued for the use of proline, 2methyl-4-carboxy-5-hydroxy-3,4,5,6,-tetrahydropyrimidine THP(A) and 2-methyl-4-carboxy-3,4,5,6-tetrahydropyrimidine THP(B) to increase the thermal stability of DNA polymerases at high temperatures [36], whereas THP(B) can lower the melting temperature of doublestranded DNA. US Patent 6783940 was issued for a technique that further improves the PCR condition by including sorbitol or sorbitol and DMSO in the PCR mixture, which is effective for reducing the non-specific amplification [37]. Sorbitol at a concentration of $0.15 \mathrm{M}$ results in an increase in specific target DNA.

Hot-start PCR can increase the reaction specificity by inhibiting the activity of DNA polymerase during the sample preparation step. In hot-start PCR, DNA polymerase is bound to an antibody that is inactivated and dissociated from the DNA polymerase by heat denaturation. The major drawback is that the anti-polymerase antibody is expensive and only specific to a particular polymerase. US Patent 6403341 was issued for a method of inactivating the DNA polymerase by keeping the concentration of magnesium ions low [38], and this method is as efficient as hot-start PCR. The magnesium ions added in the reac- 
tion mixture are in precipitate form. Without magnesium ions, the DNA polymerase is inactive and no non-specific reaction occurs. Upon raising the temperature, magnesium ions are released from the precipitate. Magnesium ions are mixed with various phosphates in a tube to form precipitate. After precipitation, PCR components are added into the tube and PCR is then performed. In our view, this method may not be easy to reproduce as it is difficult to aliquot the precipitate accurately into individual tubes. Researchers should find a form of sequestered magnesium ions that can be stored and aliquoted as a solution. Upon heating, the sequestered ions are then released and the PCR reaction takes place.

The amplification success rate of PCR can be further increased by finding a superior polymerase or a better formulated PCR buffer. Such improvements would enhance the DNA amplification processes and may decrease the amount of template required. The latter is relevant to the amplification of DNA from medicinal materials, as in many cases the DNA of processed material is difficult to extract or highly degraded. Also, DNA extracted from dried medicinal materials may be contaminated with phytochemicals that can inhibit the amplification process. Improvements in the PCR buffer and DNA polymerase may overcome such inhibition and increase the amplification success rate.

\section{Patents for the generation of species-specific fingerprints and sequences}

Commercial ginseng products come in the form of powder or shredded slices, rendering authentication by morphological and histological methods unpractical. Chemical analysis is limited by the available amount of chemical markers, ginsenosides, which are significantly affected by such factors as storage conditions, freshness of products, and post-harvesting processing. The techniques described in this section are patentable because they are improved technologies that can solve the authentication difficulties.

US Patent 5876977 was issued for a method of fingerprinting ginseng by taking advantage of the unique PCRRFLP patterns of different ginsengs [39]. The form or the physical and chemical conditions of the sample do not appear to affect the outcome of the method. The internal transcribed spacer (ITS) region of the rDNA of herbal material is highly polymorphic between different species and is amplified by primers that bind to the conserved regions. The PCR products are then fragmented by selected restriction endonuclease. After electrophoresis, discrete and species-specific RFLP patterns are generated. The ITS sequences of several medicinal species, including Panax ginseng (Renshen), Panax quinquefolius (Xiyangshen), and Codonopsis (Dangshen) species, have been patented. More than one distinctive RFLP profiles can be generated by digesting these DNAs with different restriction enzymes, which makes the interpretation of results straightforward. Chinese Patent 01102434 employs the same approach to authenticate other herbal materials [40]. The ITS sequences of 16 medicinal Dendrobium species and adulterant Pholidota cantonensi may also be beneficial to the horticulture industry. Patents for authenticating high-value Chinese medicinal materials are summarized in Table 1.

Besides the ITS region, 5S rRNA intergenic spacer (5S rRNA) has also been employed to authenticate medicinal material. US Patent 6569625 was issued for a method of differentiating four medicinal Fritillaria species using this

Table I: Patents for using DNA techniques to authenticate high-value Chinese medicinal materials

\begin{tabular}{|c|c|c|c|}
\hline Medicinal material & Description of the patent & DNA techniques & Patent number \\
\hline \multirow[t]{3}{*}{ Radix Et Rhizoma Ginseng (Renshen) } & $\begin{array}{l}\text { Distinguish Panax ginseng from Panax quinquefolius, } \\
\text { distinguish Codonopsis species and adulterants }\end{array}$ & PCR-RFLP & US Patent 5876977 \\
\hline & $\begin{array}{l}\text { Differentiate wild ginseng, cultivated ginseng, and } \\
\text { adulterants }\end{array}$ & PCR-RFLP & Chinese Patent 200410016240 \\
\hline & $\begin{array}{l}\text { Distinguish Panax ginseng from Panax quinquefolius and } \\
\text { adulterants }\end{array}$ & SCAR & US Patent 6803215 \\
\hline Caulis Dendrobii (Shihu) & $\begin{array}{l}\text { Distinguish } 16 \text { Dendrobium species and adulterants from } \\
\text { each other }\end{array}$ & PCR-RFLP & Chinese Patent 01102434 \\
\hline \multirow[t]{3}{*}{ Cordyceps (Dongchongxiacao) } & $\begin{array}{l}\text { Distinguish Cordyceps sinensis from seven related } \\
\text { species }\end{array}$ & PCR-RFLP & Chinese Patent 99106135 \\
\hline & $\begin{array}{l}\text { Distinguish Cordyceps sinensis from seven related } \\
\text { species }\end{array}$ & PCR-RFLP & US Patent 6271003 \\
\hline & $\begin{array}{l}\text { Distinguish Cordyceps sinensis from seven related } \\
\text { species }\end{array}$ & DNA sequencing & US Patent 6251606 \\
\hline $\begin{array}{l}\text { Colla Corii Asini } \\
\text { (Ejiao) }\end{array}$ & Distinguish Equus asinus from domestic animals & PCR-RFLP & Chinese Patent 03153838 \\
\hline $\begin{array}{l}\text { Rhizoma Gastrodiae } \\
\text { (Tianma) }\end{array}$ & $\begin{array}{l}\text { Distinguish Gastrodia eleata from adulterant Lycopus } \\
\text { lucidus }\end{array}$ & SCAR & Chinese Patent 200510031346 \\
\hline
\end{tabular}


DNA region [41]. 5S rRNA is amplified by PCR and then sequenced. Each Fritillaria species has a unique spacer sequence, with the highest similarity between Fritillaria anhuiensis and Fritillaria puqiensis (97.48\%). After digestion with EcoRI, fragments of 384 bp and 314 bp from Fritillaria cirrhosa and 460 bp and 123 bp from Fritillaria thunbergii are obtained, while the PCR products of Fritillaria anhuiensis and Fritillaria puqiensis are not cleaved. When using PCR-RFLP for rapid screening of species, the amplified region should be chosen carefully. For example, 5S rRNA intergenic spacer is a highly variable region, but there are many point mutations, insertions, and deletions among different copies of the gene in some species. As a result, the restriction profiles may not be consistent. We think that looking at the ITS or chloroplast regions of Fritillaria species may be more beneficial.

PCR-RFLP has also been used to authenticate drugs from animal sources such as the skin of donkey (Equus asinus L.), which is the raw material for the production of Ejiao used for treating anemia with dizziness, palpitation, muscular weakness; excessive menstrual discharge and tremors due to blood deficiency [42]. It is difficult to distinguish between Ejiao made from donkey and that from cow or horse because protein compositions from these animals are similar; therefore, using mass spectrometry or enzymatic analysis would not be helpful. Chinese Patent 03153838 was issued for a method of distinguishing Equus asinus from other domestic animals by amplifying partial cytochrome b gene regions (about 359 bp) from the skin of donkey, horse, cow, and mule [43]. PCRRFLP profiles are generated by digestion of DNA with HinfI, HaeIII, AluI, MboI, TaqI, and MseI. The resolution of this method could be increased if the DNA sequences of these animals were determined in order to provide more information.

Another group has designed a testing kit for distinguishing Eriocheir japonica sinensis (hairy crabs) from Eriocheir japonica hepuensis. Hairy crab is popular with the medicinal value of removing heat from the stomach and liver and healing bone fractures [44]. Chinese Patent 01127215 was issued for a testing kit with a pair of specific primers and DraI restriction enzyme [45]. A 293-bp DNA fragment is amplified with the specific primers and then digested with DraI. For Eriocheir japonica hepuensis, the DNA is cleaved at position 188 and two fragments are generated. There is no DraI site in the corresponding DNA of Eriocheir japonica sinensis, and therefore its DNA remains intact after digestion.

Cordyceps is a composite consisting of the stroma of the fungus Cordyceps sinensis, which parasitizes on the caterpillars of some moth. It is used to tonify the lung and kidney, arrest bleeding, and dissolve phlegm. Despite the many adulterants in the herbal market, prior classification methods based on configuration, physiology, or biochemistry could not provide an accurate and reliable classification of Cordyceps sinensis. Chinese Patent 99106135 and US Patent 6271003 were issued for a novel method for distinguishing Cordyceps sinensis from seven closely related fungal species [46,47]. The $18 \mathrm{~S}$ rRNA region of genomic DNA is amplified and the PCR products are digested separately with four restriction enzymes. Based on the generated fingerprints, $C f o I$ produces restriction fragments of 570, 300, and 50 bp in C. sinensis. Phytocordyceps ninchukispora also has three fragments, but the sizes are different $(830,320$, and $150 \mathrm{bp})$. Five fragments are produced in Cordyceps militaris, and the PCR products of five other fungal species are not cleaved. The 18S rRNA gene was then sequenced and compared in US Patent 6251606 [48]. All Cordyceps sinensis specimens have the same $18 \mathrm{~S}$ rRNA gene sequence, which distinguishes them from related species. As compared with PCR-RFLP, DNA sequencing provides more information down to the base level while PCR-RFLP is much faster and is more suitable for screening. While the technology gives clear PCR-RFLP fingerprints for the fungi, it may not be easy to apply to Cordyceps, because both the 18S rRNA sequence of Cordyceps sinensis and the moth are amplified, and the resulting PCR-RFLP pattern may be confusing. For improvement, it may be necessary to design fungal-specific primers so that only the fungal DNA is amplified. In addition, because the $18 \mathrm{~S}$ rRNA gene is rather conserved, possibly leading to inadequate resolution, other highly variable regions, such as an ITS, should be considered.

Random amplified polymorphic DNA (RAPD) is another simple and fast DNA technique for generating fingerprints for medicinal materials. To identify an unknown sample, DNA from a known species is used as a standard control. After electrophoresis, the identity of the sample can be determined by matching it to the profile of a reference sample. However, RAPD fingerprints may be affected by the purity and integrity of the DNA template, type of DNA polymerase, and thermocycler used. On the other hand, polymorphic bands generated from RAPD are a good starting point for performing SCAR (Figure 3). US Patent 6803215 was issued for the use of SCAR to differentiate plant and animal medicinal materials, including Panax and medicinal snakes [49]. SCAR requires only one PCR step; thus, SCAR is more efficient than the PCR-RFLP approach described in US Patent 5876977 [39]. Polymorphic regions of ginseng were first identified by RAPD or direct amplification of length polymorphism (DALP), and several sets of SCAR primers were then designed to distinguish Panax ginseng and Panax quinquefolius and their adulterants. For animal samples, polymorphic bands that distinguished between the snake species Agkistrodon actus, Bungarus multicinctus, and Zaocys dhumandes were 

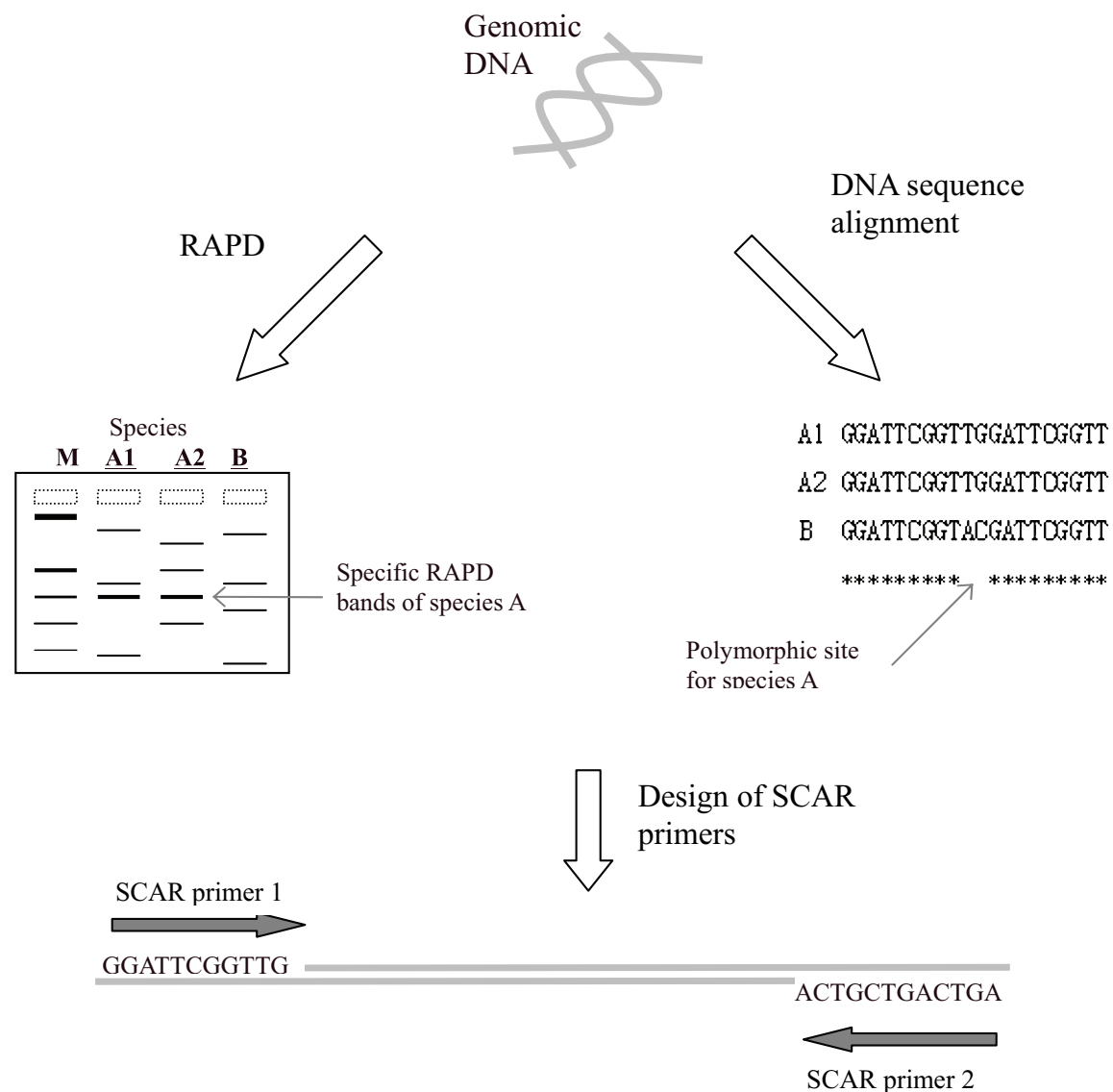

PCR using SCAR

primers

\section{Figure 3}

SCAR primers can be designed from a whole-genome fingerprint, such as RAPD analysis or comparison of the DNA sequences among species. During RAPD, genomic DNA is amplified by a RAPD primer. A polymorphic band is recovered from agarose gel and then sequenced. The RAPD band is turned into a species-specific SCAR marker.

first produced by RAPD. These bands were sequenced for the design of SCAR primers, which are species-specific. The primers do not amplify DNA of other snake species or common domestic animals.

Chinese Patent 200410016240 was issued for a technique that differentiates wild ginseng from cultivated ginseng and adulterants. Two set of primers were designed based on the polymorphic DNA generated by DALP [50]. The first primer set only amplifies the genomic DNA of cultivated ginseng and produces a 174-bp PCR product. The second primer set can detect wild and cultivated ginseng and produces a 300-bp PCR product. These four primers can be used in multiplex PCR, which greatly increases the efficiency of the test. 
SCAR primers can also be designed from an internal polymorphic site of the DNA (Figure 3). Chinese Patent 00134133 was issued for a process of generating SCAR primers using this approach [51]. Radix et Rhizoma Rhei (Dahuang) is the dried root and rhizome of Rheum palmatum, R. tanguticum, or R. officinale. Its indications include fever with constipation, retention of feces, abdominal pain, and jaundice caused by damp-heat. Chloroplast intergenic spacer $\operatorname{trn} \mathrm{L}-\mathrm{F}$ of three genuine species and 10 closely related Rheum species were amplified by PCR amplified, and the PCR products were sequenced and aligned. At position 221, the nucleotide for the three genuine species is cytosine while that of the other Rheum species is adenine. A pair of specific primers was designed based on this polymorphic site. The three genuine species produce a single 300-bp band after SCAR and the other species give a negative result. Similarly, Chinese Patent 200510031346 was issued for a SCAR sequence for differentiating between Gastrodia eleata (Tianma) and its adulterant Lycopus lucidus (Zelan) [52]. With increasing DNA sequences available in the public sequence databases, we have a convenient resource for primer design.

In general, it takes time to identify species-specific SCAR markers, but once found and specific primers designed, authentication of unknown samples becomes simple and routine. SCAR products are specific, as stringent conditions are used when amplifying the DNA. To further improve the resolution and sensitivity of SCAR and DALP, it is important to determine and use highly variable DNA regions and fluorescent primers.

\section{Patents for high-throughput detection and identification of unknown DNA}

DNA identification by PCR-RFLP relies on the presence of restriction cutting sites in the amplified DNA sequence. In the absence of an expected cutting site, which may result from a sequence polymorphism, authentication of a specimen is not possible. Use of DNA hybridization may yield results that are difficult to interpret because hybridization signals may be low. US Patent 7297490 was issued for a novel DNA microarray that provides a high-throughput approach for authenticating Chinese medicinal materials by making use of the variable ribosomal RNA sequences for generating the array [53]. Three medicinal plants, Ilex asprella, Ilex latifolia, and Ilex rotunda, were employed. ITS regions of these samples were first sequenced and compared. Primers were designed for the amplification of the polymorphic ITS- 1 and ITS- 2 regions. The amplified fragments are spotted onto a nylon membrane. To generate the probe, the whole ITS- 1 and ITS- 2 sequences are amplified and labeled by DIG-High Prime. After hybridizing the probes to the nylon membrane, signals are detected by DIG Nucleic Acid Detection Kit. When the probe from a particular Ilex species is hybridized to the DNA of its own species, a stronger signal is obtained.

\section{Development after patent application}

Patentable advancements have been made in DNA authentication, ranging from the extraction of DNA to high-throughput detection. In particular, inventions that improve the existing protocols for DNA extraction and PCR would have high market value because they can be easily incorporated into existing products. In addition, patented DNA sequences may be employed for designing primers in testing kits or DNA microarrays. Substantial investment will be needed for generating new types of equipment, such as a new DNA extractor. In this case, a patent or a patent application would be especially valuable in terms of securing financial support for developing the technology. After applying for a patent, the inventor would begin to seek for support to further develop the invention. Nevertheless, the application may sometimes be abandoned [54-58], if it is found to have little commercial interest.

\section{Conclusion}

While the demand for DNA authentication is still restricted to endangered, toxic, or high-value medicinal materials, with regulations that require more accurate authentication of herbal materials and an increasing demand for high-quality herbs, the market demand for DNA authentication of medicinal materials will increase, thereby increasing the number of patents for new technologies. Improvements to existing technologies are expected to further advance the field of DNA authentication of herbal materials.

\section{Competing interests}

The authors declare that they have no competing interests.

\section{Authors' contributions}

PCS coordinated the project, revised and edited the manuscript. KLW drafted the manuscript. AWKC and WCW advised on the patent application process and commented on the patents. PPHB advised and revised the manuscript. All authors read and approved the final version of the manuscript.

\section{Additional material}

\section{Additional file 1}

Patentability of some inventions. This table lists the patent number and reasons for patentability.

Click here for file

[http://www.biomedcentral.com/content/supplementary/17498546-4-21-S1.DOC] 


\section{Additional file 2}

Some abandoned Chinese patent applications. This table lists the patent application number, area of work and description of the patent and possible reasons for abandoning the application.

Click here for file

[http://www.biomedcentral.com/content/supplementary/17498546-4-21-S2.DOC]

\section{Acknowledgements}

This study in PCS's laboratory for DNA authentication of Chinese medicinal material was supported by a strategic research grant from the Chinese University of Hong Kong.

\section{References}

I. But PPH, Tomlinson B, Cheung KO, Yong SP, Szeto ML, Lee CK: Adulterants of herbal products can cause poisoning. $B M J$ 1996, 313:117.

2. Johanns ES, Kolk LE van der, van Gemert HM, Sijben AE, Peters PW de Vries I: An epidemic of epileptic seizures after consumption of herbal tea. Ned Tijdschr Geneeskd 2002, 146:813-816.

3. Lo SHK, Mo KL, Wong KS, Poon SP, Chan CK, Lai CK, Chan A: Aristolochic acid nephropathy complicating a patient with focal segmental glomerulosclerosis. Nephrol Dial Transplant 2004, 19:1913-1915.

4. Lee S, Lee T, Lee B, Choi H, Yang M, Ihm CG, Kim M: Fanconi's syndrome and subsequent progressive renal failure caused by a Chinese herb containing aristolochic acid. Nephrology 2004, 9(3): 126-129.

5. Vanherweghem JL, Depierreux M, Tielemans C, Abramowicz D, Dratwa M, Jadoul M, Richard C, Vandervelde D, Verbeelen D, Vanhaelen-Fastre R: Rapidly progressive interstitial renal fibrosis in young women: association with slimming regimen including Chinese herbs. Lancet I993, 34 I (8842):387-391.

6. Committee on Chinese Medicine and Pharmacy, Department of Health, Executive Yuan, Taiwan [http:// www.ccmp.gov.tw./bulletin/

announce detail.asp? $\mathrm{no}=\mid 34 \&$ selno $=620 \&$ relno $=620 \& \mathrm{PageNO}=1]$

7. Yip PY, Chau CF, Mak CY, Kwan HS: DNA methods for identification of Chinese medicinal materials. Chin Med 2007, 2:9.

8. Zhang YB, Shaw PC, Sze CW, Wang ZT, Tong Y: Molecular authentication of Chinese herbal materials. J Food Drug Ana 2007, I 5(I): I-9.

9. Williams JGK, Kubelik AR, Livak KJ, Rafalski JA, Tingey SV: DNA polymorphisms amplified by arbitrary primers are useful as genetic markers. Nucleic Acids Res 1990, 18(22):653 I-6535.

10. Grist SA, Firgaira FA, Morley AA: Dinucleotide repeat polymorphisms isolated by the polymerase chain reaction. Biotechniques 1993, I 5(2):304-309.

II. Vos P, Hogers R, Bleeker M, Reijans M, Lee T, Hornes M, Frijters A, Pot J, Peleman J, Kuiper M, Zabeau M: AFLP: a new techniques for DNA fingerprinting. Nucleic Acids Res 1995, 23(2I):4407-44I45.

12. Desmarais E, Lanneluc I, Lagnel J: Direct amplification of length polymorphisms (DALP), or how to get and characterize new genetic markers in many species. Nucleic Acid Res 1998, 26(6): $1458-\mid 465$.

13. Cheung KS, Kwan HS, But PPH, Shaw PC: Pharmacognostical identification of American and Oriental ginseng roots by genomic fingerprinting using arbitrarily primed polymerase chain reaction (AP-PCR). J Ethnopharmacol 1994, 42(I):67-69.

14. Gillan R, Cole MD, Linacre A, Thorpe JW, Watson ND: Comparison of Cannabis sativa by random amplification of polymorphic DNA (RAPD) and HPLC of cannabinoids: a preliminary study. Sci Just 1995, 35(3): 169-177.

15. Guo BL, Wu M, Si JP, Li JS, Xiao PG: Research on DNA molecular marker of Magnolia officinalis Rehd. et Wils.: -RAPD study on certified species. Yaoxue Xuebao 200I, 36(5):386-389.

16. Ha WY, Shaw PC, Liu J, Yau FCF, Wang J: Authentication of Panax ginseng and Panax quinquefolius using amplified fragment length polymorphism (AFLP) and directed amplification of minisatellite region DNA (DAMD). J Agric Food Chem 2002, 50(7): $187 \mid-1875$

17. Fushimi H, Komatsu K, Isobe M, Namba T: Application of PCRRFLP and MASA analyses on I8S ribosomal RNA gene sequence for the identification of three Ginseng drugs. Biol Pharm Bull 1997, 20(7):765-769.

18. Nakai R, Shoyama Y, Shiraishi S: Genetic characterization of Epimedium species using random amplified polymorphic DNA (RAPD) and PCR-restriction fragment length polymorphism (RFLP) diagnosis. Biol Pharm Bull 1996, 19(1):67-70.

19. Fu RZ, Wang J, Zhang YB, Wang ZT, But PPH, Li N, Shaw PC: Differentiation of medicinal Codonopsis species from adulterants by polymerase chain reaction--restriction fragment length polymorphism. Planta Med 1999, 65:648-650.

20. Germini A, Zanetti A, Salati C, Rossi S, Forre C, Schmid S, Marchelli R, Fogher C: Development of a seven-target multiplex PCR for the simultaneous detection of transgenic soybean and maize in feeds and foods. I Agric Food Chem 2004, 52(I I):3275-3280.

21. Nandi B, Nandy RK, Mukhopadhyay S, Nair GB, Shimada T, Ghose $A C$ : Rapid method for species-specific identification of Vibrio cholerae using primers targeted to the gene of outer membrane protein ompW. I Clin Microbiol 2000, 38(II):4I45-4I5I.

22. Soltis DE, Soltis PS: Choosing an approach and an appropriate gene for phylogenetic analysis. In Molecular Ssystematics of Plants. II. DNA Sequencing Edited by: Soltis DE, Soltis PS, Doyle JJ. Boston: Kluwer Academic Publishers; 1998: I-42.

23. Zhang YB, Wang J, Wang ZT, But PPH, Shaw PC: DNA microarray for identification of the herb of Dendrobium species from Chinese medicinal formulations. Planta Med 2003, 69: I I72-1 174.

24. Sze SC, Zhang KY, Shaw PC, But PP, Ng TB, Tong Y: A DNA microarray for differentiation of (Fengdou Shihu) by its $5 S$ ribosomal DNA intergenic spacer region. Biotechnol Appl Biochem 2008, 49:149-154.

25. US Patent and Trademark Office [http://www.uspto.gov/web/ patents/howtopat.htm

26. Felton M: The patent machine. Mod Drug Discov 200I, 9:5I-52.

27. State Intellectual Property Office of the People's Republic of China [http://www.sipo.gov.cn/sipo/zlsq/]

28. Weeden NF, Loomis D, Celeste JA: Matrix mill for DNA extraction. US Patent 60636162000.

29. Weber SA, Douglas DK, Kreader C: Compositions and methods for nucleic acid extraction from biological samples. US Patent 72 I 44842007.

30. Thomas S, Tilzer L, Moreno R: Use of gel polymer for DNA extraction with organic solvents. US Patent 5/06966 1992.

31. Mullis Kary B: Process for amplifying nucleic acid sequences. US Patent 1987.

32. Hagen FS: Directional cloning. US Patent 5075227 I99I.

33. Caskey CT, Chamberlain JS, Gibbs RAL, Ranier JE, Nguyen PN: Multiplex genomic DNA amplification for deletion detection. US Patent 55829891996

34. Gelfand DH, Myers TW: Reverse transcription with thermostable DNA polymerase--high temperature reverse transcription. US Patent 53106521994.

35. Kosak KM, Kosak M: Reactions using heat-releasable reagents in wax beads. US Patent 56437641997.

36. Lapidot A, lakobashvili R, Malin G: Methods for DNA amplification and sequencing. US Patent 7/50980 2006.

37. McLaughlin IJ, Coticone SR, Bloch W: Method of reducing nonspecific amplification in PCR. US Patent 67839402004.

38. Barnes WM, Rowlyk KR: Magnesium precipitate hot start method for PCR. US Patent 640334I 2002.

39. Wang J, Shaw PC, But PPH, Ngan KFN: Polymerase chain reaction--restriction fragment length polymorphism test for the authentication of traditional Chinese medicines. US Patent 5876977 I 999.

40. Shaw PC, Wang J, But PPH, Lau DTW: DNA sequence of Dendrobium and method for discriminating its variety and judging if it is true or false. Chinese Patent 011024342001.

4I. Tsim KWK, Ip NY, Sucher NJ: Fritillaria species identification. US Patent 65696252004

42. Pharmacopoeia Editorial Committee: Pharmacopoeia of the People's Republic of China. Shanghai 2005.

43. Zhang A, You JH, Xie FS: Methods for identifying animal hide and skin. Chinese Patent $03 / 538382003$. 
44. Health Department and National Chinese Medicine Management Office: Zhonghua Bencao. Shanghai 1999.

45. Zhou KY, Sun HY, Yang G: PCR/RFLP molecular assay method for Chinese and Hepu Eriocheir sinensises and its reagent kit. Chinese Patent 0II 272152001.

46. Xu RX, Chen ZH: Process for identifying Cordyceps. Chinese Patent $99106 / 351999$.

47. Hseu RS, Chen CS: Method for identifying Cordyceps sinensis. US Patent 627I003 200I.

48. Hseu RS, Chen CS: Gene sequence and method for distinguishing Cordyceps sinensis. US Patent 6251606 200I.

49. Shaw PC, Wang J, But PPH, Ha WY, Yau FCF: Sequence characterized amplified region (SCAR) test for the authentication of traditional Chinese medicinal materials. US Patent 6803215 2004.

50. Zhang WJ, Wan SW, Cheng Z: Molecular mark of wild mountain ginseng and discrimination method therefore. Chinese Patent 2004100162402004.

5I. Yang MH, Zhang DM, Zheng JH: Certified rhubarb product identifying method and reagent kit. Chinese Patent 00/34/332000.

52. Tao J, Luo ZY, Tao Y: Rhizoma gastrodiae-specific DNA molecule labelled series and its application. Chinese Patent 2005/003/346 2005

53. Kwan HS, Mak CY, Hon PK, Lau OW: Authentication of biologic materials using DNA-DNA hybridization on a solid support. US Patent 72974902004

54. Xu DB, Zhu DF, Sun CR: PCR method adopting high-concentration glycerine and its reaction liquid and application. Chinese Patent 03/I70/4 2003.

55. Koizumi T, Hamano Y, Yamamoto B: Method for improving DNA amplification reaction efficiency. Chinese Patent 03 / 478062003.

56. Sun Q: Method of identifying truth of Chinese herbal medicines. Chinese Patent 011044572001.

57. Li TX, Wang JK, Lu ZH: Preparation process of Chinese medicine material gDNA germ plasm specificity micro array chip. Chinese Patent 03/32205 2003.

58. Li TX, Wang JK, Lu ZH: Specific gDNA probe for germplasm identification of five kinds of Dendrobium. Chinese Patent 2004100142592004.

Publish with Bio Med Central and every scientist can read your work free of charge

"BioMed Central will be the most significant development for disseminating the results of biomedical research in our lifetime. "

Sir Paul Nurse, Cancer Research UK

Your research papers will be:

- available free of charge to the entire biomedical community

- peer reviewed and published immediately upon acceptance

- cited in PubMed and archived on PubMed Central

- yours - you keep the copyright
BioMedcentral 